\title{
Postgraduate Education for Internal Auditors Versus Employers' Expectations
}

\author{
LENA GRZESIAK \\ Department of Human Resources Management, Faculty of Management, \\ University of Lodz
}

This research is part of a larger project on internal audit education. It has been kindly supported by a research grant for young scientists under contract No. B1812100001865.02.

\begin{abstract}
The content and structure of postgraduate courses in internal auditing are analysed to compare them with Polish employers' expectations about internal auditors' competencies. The paper was prepared based on a review of the literature and analysis of 43 online job ads for internal auditors and 19 postgraduate internal auditing courses available from 17 higher schools in Poland. The comparative analysis of postgraduate courses for internal auditors and employers' expectations regarding the professionals' characteristics revealed the weaknesses of the former and their limited ability to provide public and private organisations with the right types of specialists. Educational institutions were found to underestimate the importance of internal auditors' soft skills.
\end{abstract}

Keywords: internal audit, internal audit education, postgraduate education for internal auditors, internal auditors' competencies 


\section{Introduction}

The author's interest in internal auditor education was prompted by the increasing importance of internal audits for organisational performance and by organisations' growing demand for internal auditors with specialist knowledge of their industries. Also, articles by authors such as Neumann (1972), Phillips and Lewis (1991), Hassall et al. (1996), Marks (2001) and Vinten (2004) encouraged further research into the match between postgraduate education for internal auditors and employers' expectations.

According to Bailey (2010), the internal auditor is one of the 'hottest' professions globally with growth opportunities. This prediction is somewhat challenged by Fernandes' observation (Fernandes, 1994) that most universities fail to impart solid knowledge of internal auditing and hands-on experience to their students, and that many teaching programmes have a problem following the recent developments in the internal auditing world. The observation implies that both education providers and employers should give more attention to the needs, competencies and qualifications of internal auditors so that they can develop their careers and support their organizations (Seago, 2016).

It is out of the question today that internal auditors' ability to monitor and improve risk management and internal control processes in organizations is related to the quality and comprehensiveness of their education. The value, usefulness and quality of internal audits can be measured by the auditor's education, training and certificates (Sarens, 2009).

The International Standards for the Professional Practice of Internal Auditing (hereinafter: The Standards) state that internal auditors should continue their professional education beyond its formal stages and to support organisations with all their knowledge and skills. As the representatives of a publicly trusted profession, internal auditors must also meet above-average ethical standards.

The performance of internal auditors has been known for some time now to depend not only on their knowledge of auditing procedures and rules, financial and organisational processes, but also on their mental skills and the ability to communicate with employer's personnel who are the most knowledgeable the of areas selected for auditing. The ability is based on a range of competencies and soft skills that require special training and education to be developed and sustained (the Standards).

Internal auditors can acquire and develop hard and soft skills and professional expertise through self-learning, courses, workshops, as well as using more formal postgraduate education offered by specialised providers. Postgraduate courses and training are not only a source of solid knowledge delivered by competent teachers 
but also a platform for students to support each other and exchange information and experience. Postgraduate courses are also a chance for active internal auditors to consolidate their knowledge, and a door to a new career for those who want to enter the profession.

The above facts led the author to formulate the following research questions:

- Is postgraduate education for internal auditors of sufficient quality for the students to become full-fledged internal auditors?

- Do the range and quality of postgraduate programmes for internal auditors meet employers' expectations?

The paper is organised as follows. Part 1 explains why the study was undertaken and why it is important to have a deep and up-to-date knowledge about internal audit education. In part 2 the research methodology is described and in part 3 the results and conclusions from the research as well as future directions of research on internal audit education are presented.

\section{The importance of internal auditing education}

The Institute of Internal Auditors (hereinafter: IIA) understands internal auditing as: "an independent, objective assurance and consulting activity designed to add value and improve an organisation's operations. It helps an organisation accomplish its objectives by bringing a systematic, disciplined approach to evaluate and improve the effectiveness of risk management, control, and governance processes".

Internal audit has evolved from a purely supervisory activity to a function comprising a wide range of activities intended to add value to organisations. Today's internal auditors are perceived as fraud busters (Hillison et al., 1999), a deterrent to corporate irregularities (Uecker et al., 1981), internal consultants (White, 2007), or in internal auditors' own metaphorical words, guardian angels, navigators, watchdogs, policemen or organisation's gurus (Kabalski \& Grzesiak, 2017).

The heart of the internal audit function is competent specialists who perform their duties to the best of their knowledge and adhere to the professional principles laid out in the Standards and the Code of Ethics. The principles include integrity, objectivity, making judgements based on evidence, impartially and without prejudices; confidentiality requiring that no classified information be disclosed unless such a disclosure is properly authorised by its proprietor; and competency. The Standards also state that internal auditors must provide their services competently and with due professional care, and improve their expertise, skills, and competencies on an ongoing basis. 
To be able to deliver value-adding assurance and consulting services to their clients, internal auditors also need excellent soft skills (attitudes, beliefs, values, verbal and written communication skills, analytical and critical thinking skills, etc.) and hard skills (e.g. Winiarska, 2017a; Bailey, 2010; Moeller, 2011; The Standards)

Teaching programmes for internal auditors are effective when their design is based on:

- a good understanding of the nature of the current and future challenges faced by the profession;

- the awareness that education and training for internal auditors must be improved as the complexity of business processes increases;

- teaching activities stimulating the development of specific professional competences and skills.

In Poland, prospective internal auditors can choose from a variety of undergraduate, graduate or postgraduate programmes, or sign up for one of many specialist courses offered by professional organisations such as the Institute of Internal Auditors. The most efficient and practical options seem to be postgraduate education, which is designed to meet the needs of novice internal auditors as well as active professionals.

\section{Education for internal auditors in the light of research}

The conclusions of studies on different aspects of internal auditor education can be summarised as follows:

- the teaching programmes for internal auditors should be jointly developed by schools and practitioners (Rezaee, 1994);

- some problems within internal audit education need to be urgently addressed to improve its quality and the quality of performance of internal auditors; there is a need to make teaching programmes more flexible so that they can meet the increasing demand for internal auditors' services without unnecessary delay (Boța-Avram \& Pop, 2009);

- employers prefer experienced auditors over recent graduates; a South-African study with a sample of practising internal auditors from 273 organizations (Clune \& Gramling, 2012) revealed that $42 \%$ of the organisations neither hired nor planned to hire recent graduates;

- applied business communication courses have obvious benefits, such as the promotion of teamwork, a confidence-building effect, and the improvement of students' presentation skills and ability to effectively communicate in workplace settings (Plant \& Slippers, 2015) 
The author's review of studies on internal audit education did not reveal any works assessing how well postgraduate courses for internal investors met employers' expectations, all the more studies making such assessments based on job adverts and postgraduate curricula. To the author's best knowledge, the only Polish study in this field was conducted by Winiarska (2017a), who presented a meta-analysis of international reports on the quality of internal audit education.

\section{Methodology}

The data necessary for this study were collected between April and May 2018 and between September 17 and $202018 .^{1}$

In the first period, the job adverts for internal auditors posted by public and private employers were reviewed, excluding opportunities for trainees and inexperienced auditors. The purpose of the review was to determine internal auditors' characteristics sought by employers.

Job adverts come with a number of advantages as a source of research data (Rafaeli and Oliver 1998; Cullen, 2000; Harper, 2012; Faberman \& Kudlyak, 2016) because there are plenty of them, researchers can compile samples of any size and structure, and a large pool of up-to-date, domestic and international data can be readily accessed. Job adverts allow employers' demand for different types of internal auditor specialists to be studied. Job adverts show what internal auditors' qualifications and competences are in demand now and what employers may expect in the future.

The job adverts used in this study were sourced from www.indeed.com, one of the most popular websites ${ }^{2}$ providing access to job listings from thousands of local websites (www.indeed.com). All job adverts available through indeed.pl are comparable because those that do not meet the standard format are not accepted.

To find job adverts meeting the purpose of the research, the author created a query procedure based on key words such as internal auditor, junior internal auditor, senior internal auditor, internal audit specialist and internal audit position in three languages (German, English and Polish).

Adverts seeking chief internal auditors were rejected because the position combines managerial responsibilities with 'pure' auditing duties. Adverts that were out-ofdate (8), offered positions outside Poland (4) or internships/postgraduate training

1 The research process was suspended for the summer when fewer adverts are available.

2 Online job adverts are reported to be more effective in reaching candidates than traditional adverts in newspapers (Kim and Angnakoon, 2016). 
in internal audit (2), had the same content (2), or were unrelated to internal auditing ${ }^{3}$ (2) were also omitted.

Of 61 selected adverts, 18 were removed from the analysis as irrelevant. The final sample consisted of 43 adverts and was accepted as large enough to produce valid results.

The next step involved the coding of the information contained in the adverts. After all relevant data were entered into a Microsoft Excel spreadsheet, the key characteristics of candidates expected by employers were identified. Subsequently, the structure indicators were applied to see how many times particular characteristics were indicated.

In the coding process, the following criteria were used (1) education, (2) experience, (3) hard skills, (4) soft skills, (5) attitudes, (6) others.

The database thus created was evaluated several times for data correctness before quantitative and qualitative analysis was performed.

The sample of Polish higher schools offering postgraduate courses in internal auditing was compiled from the Ranking of Academic Institutions (RAI) 2017 published by an educational portal Perspektywy.pl, which covers all public and private providers of tertiary education in Poland (but the fine and performing arts schools) that are authorised to award the $\mathrm{PhD}$ degree or the habilitated doctor degree. The ranking enjoys high reputation with Polish and international academic circles.

The top 20 universities, 20 universities of technology and 6 universities of economics were analysed to find out which of them provided postgraduate programmes for internal auditors. As a result, a sample of 17 universities offering a total of 19 courses was created (9 universities, 2 universities of technology and 6 universities of economics). The number of courses exceeds the number of providers because two of them offered two different courses.

The analysis focused on courses provided in the academic year 2017/2018 because it was the last year covered by the RAI, and because some university websites were not updated when the research commenced. When the word audit in a course title was unrelated to internal audit (e.g. having to do with external audit of financial statements or energy audit, etc.), the course was excluded from the analysis, likewise outdated courses that universities had failed to remove from their websites.

The conclusions of the study are based on logical reasoning.

To the author's knowledge, there are no other studies using this combination of data sources to investigate the aspects of education for internal auditors.

\footnotetext{
3 In one advert a security job was described as 'an overnight internal auditor'.
} 


\section{Analysis of data}

\section{The analysis of job adverts}

The analysis of job adverts showed that internal auditors were primarily sought by private and public financial institutions which posted 10 out of 43 adverts analysed. Private and public employers needed internal auditors of different specialisation and offered them full-time jobs, part-time jobs and temporary replacement positions with employment contracts. Table 1 shows the numbers of job adverts for internal auditors by position and employer's sector of ownership.

Table 1. Numbers of adverts for internal auditors by job title and employer's sectors

\begin{tabular}{|c|c|c|c|}
\hline Position & No. of adverts & Private sector & Public sector \\
\hline an internal auditor & 27 & 17 & 10 \\
\hline a junior internal auditor & 4 & 4 & \\
\hline a senior internal auditor & 3 & 3 & \\
\hline an internal audit assistant & 1 & & 1 \\
\hline an internal auditor - a compliance specialist & 1 & 1 & \\
\hline a credit risk internal auditor & 1 & 1 & \\
\hline a logistics internal auditor & 1 & 1 & \\
\hline a corporate functions internal auditor & 1 & 1 & \\
\hline an internal audit - financial \& operational auditor & 1 & 1 & \\
\hline an internal auditor - a finance specialist & 1 & 1 & \\
\hline an internal auditor - a senior consultant & 1 & 1 & \\
\hline an internal auditor - a GRC specialist & 1 & 1 & \\
\hline Total & 43 & 32 & 11 \\
\hline
\end{tabular}

Source: own elaboration.

An interesting difference between job adverts posted by public and private employers could be seen - the former usually used a generic term internal auditor and the latter tended to specify the organisational area for which they need an internal auditor as well as the speciality of the prospective employee.

All employers clearly defined their preferences regarding applicants' skills and competencies (Table 2).

With regard to applicants' education, 4 adverts did not expect them to have any specific background. Of the other 39, 12 indicated a degree in economics, 4 in 
technology, 2 in engineering, 2 in law, and the remaining 19 wanted the candidates to hold a postgraduate certificate in internal auditing.

Table 2. Internal auditors' skills and knowledge required by employers

\begin{tabular}{|l|c|c|}
\hline \multicolumn{1}{|c|}{ Internal auditors' skills and competencies } & \% of job adverts & No. \\
\hline hands-on experience & $97.67 \%$ & 42 \\
\hline business acumen & $93.02 \%$ & 40 \\
\hline higher education & $90.70 \%$ & 39 \\
\hline knowledge of the ERP system (mainly SAP) & $86.05 \%$ & 37 \\
\hline knowledge of foreign languages & $67.44 \%$ & 29 \\
\hline knowledge of accounting & $48.84 \%$ & 21 \\
\hline project management skills & $23.26 \%$ & 10 \\
\hline internationally recognised qualifications & $20.93 \%$ & 9 \\
\hline courage to express one's opinions & $11.63 \%$ & 5 \\
\hline knowledge of the employer's industry & $11.63 \%$ & 5 \\
\hline knowledge of US GAAP and SOX & $9.30 \%$ & 4 \\
\hline knowledge of business processes & $6.98 \%$ & 3 \\
\hline
\end{tabular}

Source: own elaboration.

As far as professional certificates are concerned, 9 of the 43 job adverts required the applicants to have internationally recognised qualifications ${ }^{4}$ or certificates by the Polish Ministry of Finance. In none of the adverts was a statutory auditor's certificate indicated as a prerequisite to getting the job. In 13 adverts, the possession of the certificate was mentioned as an additional advantage. All the employers who expected the applicants to have international certificates operated in the private sector.

The above findings imply that the possession of an international certificate is not necessary for an internal auditor to be successful in the labour market, but it certainly gives its holders some advantage over those who cannot use it as a proof of their professional competence and good knowledge of English.

Polish employers proved similar to their South African counterparts in that they expected applicants to have sufficient experience and the working knowledge of internal auditing, too. The length of experience indicated in the adverts was two years on average. Twenty-two adverts sought candidates with prior experience of internal auditing.

Although applicants were required to have specialist, technical knowledge of internal auditing, most of the employers did not expect them to be experts in their

\footnotetext{
${ }^{4}$ Confirmed by the CIA, CGAP, CICA, ISACA, CRMA, ACCA, CFA, CPA, CAMS, PRM, ICAAP.
} 
industry. An exception was the financial organisations which indicated that applicants should have the knowledge of their products and financial legislation.

Even though ethical conduct and integrity are enshrined in the internal auditors' code of ethics as the two pillars of the internal auditing profession, only few job adverts mentioned them. An interesting, and rather unusual, finding was that almost one-fourth of the employers expected candidates to have project management skills, which are rarely associated with this profession.

In contrast with the private employers who only wanted candidates to have a degree, the public sector employers additionally stressed that candidates should also meet the requirements of the public finance act.

The analysis of soft skills expected of candidates by the private and public employers produced interesting information on what kind of persons they wanted to have among their staff. A ranking of internal auditors' soft skills required by the employers is shown in Table 3 below.

Table 3. Internal auditors' soft skills indicated in employers' job adverts

\begin{tabular}{|c|c|l|}
\hline Not less than [\%] & Less than [\%] & \multicolumn{1}{|c|}{ Soft skills } \\
\hline 90 & 100 & $\begin{array}{l}\text { (1) analytical thinking, (2) communication skills, } \\
\text { (3) an ability to perform under stress }\end{array}$ \\
\hline 80 & 90 & (1) an ability to perform under time pressure \\
\hline 70 & 80 & (1) problem-solving skills \\
\hline 60 & 70 & (1) teamwork skills \\
\hline 50 & 60 & (1) interpersonal skills \\
\hline 40 & 50 & (1) accuracy in work, (2) analytical and critical thinking skills \\
\hline 30 & 40 & (1) organisational skills \\
\hline 20 & 30 & (1) negotiation skills \\
\hline 10 & 20 & $\begin{array}{l}\text { (1) time management skills, (2) partnership attitude, } \\
\text { (3) business acumen, (4) an ability to present meaningful } \\
\text { recommendations and conclusions }\end{array}$ \\
\hline 0 & 10 & $\begin{array}{l}\text { (1) strong work ethics, (2) self-sufficiency, (3) personal } \\
\text { culture, (4) commitment, (5) willingness to learn }\end{array}$ \\
\hline
\end{tabular}

Source: own elaboration.

Internal auditors' communication skills (written and oral) seemed to be particularly important to the employers, because only those were boldfaced or underlined in the adverts.

The ranking of the top 10 soft skills in Table 4 was created based on the number and percentage of adverts in which they were mentioned. 
Table 4. The top 10 soft skills indicated in job adverts

\begin{tabular}{|c|c|c|c|}
\hline & Soft skill & $\%$ of all adverts & no. of adverts \\
\hline 1 & analytical thinking skills & $97.67 \%$ & 42 \\
\hline 2 & communication skills & $95.35 \%$ & 41 \\
\hline 3 & ability to formulate concise and meaningful messages & $95.35 \%$ & 41 \\
\hline 4 & ability to perform under stress & $93.02 \%$ & 40 \\
\hline 5 & ability to perform under time pressure & $81.40 \%$ & 35 \\
\hline 6 & problem-solving skills & $72.09 \%$ & 31 \\
\hline 7 & teamwork skills & $62.79 \%$ & 27 \\
\hline 8 & interpersonal Skills & $55.81 \%$ & 24 \\
\hline 9 & accuracy in work & $48.84 \%$ & 21 \\
\hline 10 & critical thinking skills & $48.84 \%$ & 21 \\
\hline
\end{tabular}

Source: own elaboration.

\section{Postgraduate education for internal auditors}

Postgraduate courses for internal auditors were identified through a query using keywords such internal audit as well as (1) internal control systems, (2) management control in public sector, (3) frauds.

As a result of universities designing courses according to their own standards, needs and aims, courses had different numbers of subjects and teaching hours (Table 5).

Table 5. General description of postgraduate courses for internal auditors

\begin{tabular}{|l|c|c|c|}
\hline \multicolumn{1}{|c|}{ Position } & Average & Minimum & Maximum \\
\hline No. of teaching hours per course & $199.37\left(^{*}\right)$ & 160 & 250 \\
\hline No. of subjects & 17.16 & 11 & 22 \\
\hline
\end{tabular}

$\left({ }^{*}\right)$ without courses for which the number of hours was not stated

Source: own elaboration.

Table 6 shows teaching programmes by thematic categories created based on the subjects' names and content.

Table 6 reveals a worrying gap between postgraduate curricula for internal auditors that give relatively little attention to the development of their soft skills and the job adverts where the skills are specifically emphasised by the employers. Another problem identified in the course of analysis was that not so many subjects are taught in English. 
Table 6. Number of subjects per category

\begin{tabular}{|l|c|}
\hline \multicolumn{1}{|c|}{ Category: } & No. of subjects within a category \\
\hline management & 24 \\
\hline types of internal audit & 17 \\
\hline legislative environment & 13 \\
\hline internal audit methodology & 12 \\
\hline accounting & 11 \\
\hline control and supervision & 11 \\
\hline business environment & 8 \\
\hline soft skills & 8 \\
\hline fraud detection & 6 \\
\hline Total & 110 \\
\hline
\end{tabular}

Source: own elaboration.

The most popular subjects in internal auditing curricula are presented in Table 7.

Table 7. The most popular teaching subjects

\begin{tabular}{|c|c|c|c|}
\hline & Subject & No. of curricula & $\%$ of curricula \\
\hline 1 & IT auditing & 13 & $68 \%$ \\
\hline 2 & internal audit sampling & 13 & $68 \%$ \\
\hline 3 & public finance & 11 & $58 \%$ \\
\hline 4 & audit methodology and techniques & 11 & $58 \%$ \\
\hline 5 & internal audit standards & 9 & $47 \%$ \\
\hline 6 & financial statements audit & 9 & $47 \%$ \\
\hline 7 & financial accounting & 9 & $47 \%$ \\
\hline 8 & public procurement law & 9 & $47 \%$ \\
\hline 9 & IT auditing and audit sampling & 8 & $42 \%$ \\
\hline 10 & management control in the public sector & 8 & $42 \%$ \\
\hline 11 & public accounting & 7 & $37 \%$ \\
\hline 12 & introduction to accounting & 7 & $37 \%$ \\
\hline
\end{tabular}

Source: own elaboration.

Unlike subjects 3, 6 and 10 that specifically address the needs of the public sector, the other nine provide students with necessary knowledge to work for both public and private employers. 


\section{Discussion and conclusions for the future research}

The analysis of job adverts has shown that employers seek internal auditors with proven experience and knowledge of the job (not necessarily in the employer's industry), postgraduate education (preferably a degree in economics, law or engineering) and good IT, communication, teamwork and analytical skills, accuracy in work, resistance to stress, availability and openness to learning opportunities.

The fact that the leadership and management skills were rarely mentioned in the adverts seems to imply that employers did not find them necessary for internal auditors to produce reliable and meaningful evaluations.

Postgraduate courses for internal auditors seem to neglect the development of their soft skills in spite of employers' expectations and against the needs of the profession where "soft skills are the new hard skills" (Harrington as quoted by Chambers and McDonald, 2013). According to Frączkowska (2012, p. 61), soft skills near to experience and comprehensive knowledge are necessary for an internal auditor to be a professional and effective.

The majority of postgraduate courses for internal auditors are only taught in Polish, whereas the employers seek auditors speaking both Polish and English. Increasing the number of subjects delivered in English could improve graduates' employability and boost their careers in international settings.

Lecturing and teacher-class interaction are still widely used for instruction - only 3 of the analysed subjects involved the use of IT and internal auditing software. The approach is inefficient in the long term because it emphasises theoretical knowledge at the cost of auditors' practical skills. A cure for the problem could be the introduction of e-learning solutions and project-based assignments which would allow students to enhance their learning skills and gain practical knowledge of their profession outside the classroom.

The numbers of hours assigned to teaching programmes are insufficient for teachers to thoroughly present all aspects of some problems or to answer students' questions, which is a frustrating experience for both parties.

The authors of postgraduate courses for internal auditors seem to be unaware of the different needs of organisations in the public and private sectors.

The number of challenges faced by internal auditors keeps increasing following the fast rate of changes in economic, business and legislative environments. In this situation, their careers depend on whether they are capable of improving their knowledge and skills on an ongoing basis, and on the education providers' ability to redesign and update the content of their teaching programmes. 
To enable internal audit education to keep pace with changes taking place in organisations and legislation, more research into its needs is necessary. It should include the surveys of students, employers, internal auditors and graduates who have the knowledge necessary to answer the following questions:

- Do postgraduate courses deliver what internal auditing students expect?

- Is the knowledge they impart useful in the workplace setting?

- What is the market demand for internal auditing services?

- Which skills and competencies of internal auditors are important to employers?

The knowledge of where exactly postgraduate programmes for internal auditors fail to meet employers' expectations could guide efforts to improve the programmes' quality and adequacy. All improvements should be planned, bearing in mind that the knowledge imparted to students should enable them to cope with the specific requirements of different professional and national contexts in which internal audits are carried out.

\section{Conclusion}

The analysis of postgraduate courses and job adverts for internal auditors presented in this study was intended as a reference point for employers who wish to improve recruitment processes in their organisations and for the tertiary education institutions that want to deliver on employers' needs.

A number of weaknesses within internal audit education have been revealed. One of them is that curricula give too much emphasis to 'technical' knowledge and skills, whereas employers increasingly need internal auditors with well-developed soft skills. What they have already learnt is that professional expertise alone may not suffice when an auditor has to discuss financial irregularities, the probability of fraud or other sensitive issues with their personnel.

Another problem is that postgraduate studies for internal auditors deliver basically homogenous content, disregarding the fact that the public sector and the private sector have different needs and expectations, as well as being regulated by different laws. This approach seriously limits graduates' employability and affects their careers. What they need to be successful in their work in addition to internal auditing knowledge and skills is the awareness of the different characteristics and needs of their clients or employers and the ability to select the most appropriate tools.

Many postgraduate courses analysed in this study were found to have outdated content, falling short of the needs of contemporary organisations. This finding implies that their curricula should be reviewed and updated on a current basis so that the 
students are ready for the challenges of their profession and proficient in the use of latest advances in IT technologies.

The paper assessed the match between postgraduate education for internal auditor and the expectations of Polish employers by analysing higher schools' websites and online job adverts. The conclusions of the research were set in a broader context of the literature on internal audit education.

The paper was prepared with the aim of highlighting gaps between postgraduate programmes for internal auditors and employers' expectations in order to help educational institutions and employers to improve their curricula and recruitment processes, respectively.

\section{Limitations of the research}

Employers tend to describe their expectations in very general terms. Both factors prevented a more in-depth analysis of how well the quality and content of education for internal auditors in Poland match employers' expectations.

The main limitation of the study is related to the use of job adverts as a source of research data. Because there are too many of them, it is not possible to analyse them thoroughly. However, even a limited number of job adverts provides a wealth of information on the profiles of internal auditors sought by employers.

Another problem with job adverts is that what they show is only a snapshot of the current situation that quickly becomes outdated. They are certainly useful as a means of identifying how employers' expectations evolved in the past but are insufficient as a basis for predicting future trends.

A general conclusion that can be drawn from the study is that although job adverts can be useful as a resource of preliminary data, future research into internal audit education will have to use more sophisticated testing and analytical methods and secondary empirical methods to show its different aspects in more detail.

\section{References}

Bailey, J. (2010). Core Competencies for Today's Internal Auditory. Report II. Altamonte Springs: The Institute of Internal Auditors.

Boța-Avram, C., \& Atanasiu P. (2009). Quo vadis internal audit education? Annals of The Stefan Cel Mare University of Suceava: Fascicle of The Faculty of Economics and Public Administration, 9/2(10), 197-205. 
Chambers, R., \& McDonald, P. (2013). 7 Attributes of Highly Effective Internal Auditors. Robert Half International Inc.: The Institute of Internal Auditors.

Clune, R., \& Gramling, A. (2012). Hiring recent university graduates into internal audit positions: Insights from practicing internal auditors. Current Issues in Auditing, 6(2), A1-A14.

Cullen, J. (2000). A review of library and information service job advertisements: what do they tell us about work. Journal of Information Science, 26(4), 278-281.

Faberman, R.J., \& Kudlyak, M. (2016). What does online job search tell us about the labor market? Economic Perspectives, 40(1), 1-15.

Fernandes, J. (1994). Preparing Tomorrow's Internal Auditor. Managerial Auditing Journal, 9(2), 20-23.

Frączkowska, E. (2012). Professional competences of a future manager based on the example of professional and personality competences of internal auditor. In: $O$. Kunert (Ed.), Creative industry manager. Lodz: Wydawnictwo Politechniki Łódzkiej, 48-64.

Harper, R. (2012). The collection and analysis of job advertisements: A review of research methodology. Library and Information Research, 36(112), 29-54.

Hassall, T., Dunlop, A., \& Lewis, S. (1996). Internal audit education: Exploring professional competence. Managerial Auditing Journal, 11(5), 28-36.

Hillison, W., Pacini, C., \& Sinason, D., (1999). The internal auditor as fraud-buster. Managerial Auditing Journal, 14(7), 351-363.

Kabalski, P., \& Grzesiak, L. (2017). Funkcje audytu wewnętrznego w opinii polskich audytorów. Zeszyty Teoretyczne Rachunkowości, 91(147), 9-20.

Kim, J., \& Angnakoon, P. (2016). Research using job advertisements: A methodological assessment. Library and Information Science Research, 38, 327-335.

Marks, N. (2001). The new age of internal auditing. Internal Auditor, 58(6), 44-49.

Moeller, R. (2011). Nowoczesny audyt wewnętrzny. Warszawa: Oficyna Wolters Kluwer business.

Neumann, F.L. (1972). Auditing education - A decade of transition: And now?. Journal of Accountancy, 133(3), 87-90.

Phillips, T.J., \& Lewis, B.T., (1991). Internal audit education: The accounting curriculum's greatest deficiency. Journal of Education for Business, 66(3), 176-180.

Plant, K., \& Slippers, J. (2015). Improving the business communication skills of postgraduate internal audit students: A South African teaching innovation. Innovations In Education \& Teaching International, 52(3), 310-321.

Rafaeli, A., \& Oliver, A. (1998). Employment Ads. A Configurational Research Agenda. Journal of Management Inquiry, 7(4), 342-358.

Rezaee, Z. (1994). Importance of the 150-hour Education Requirement for Internal Auditors. Managerial Auditing Journal, 9(2), 8-11.

Sarens, G. (2009). Internal auditing research. International Journal of Auditing, 13(1), 1-7. Seago, J. (2016). Educating Auditors. Internal Auditor, 73(1), 50-53.

The Code of Ethics (2016). Florida: The Institute of Internal Auditors. 
The International Standards for the Professional Practice of Internal Auditing (2016). Florida: The Institute of Internal Auditors.

Uecker, W., Brief, A., \& Kinney, W. (1981). Perception of the Internal and External Auditor as a Deterrent to Corporate Irregularities. The Accounting Review, 56(3), 465-478.

Vinten, G. (2004). The future of UK internal audit education: Secularisation and submergence? Managerial Auditing Journal, 19(5), 580-596.

White, S.D. (2007). The auditor as internal consultant: consulting skills can boost the internal auditor's influence in the organization. Internal Auditor, 64(1), 60-64.

Winiarska, K. (2017a). Kwalifikacje audytorów wewnętrznych na świecie. Finanse, Rynki Finansowe, Ubezpieczenia, 3, 205-215.

www.indeed.com (15.11.2018).

\section{Lena Grzesiak}

Assistant at the Department of Human Resources Management of the Faculty of Management of the University of Lodz. Her research interests are interdisciplinary and include auditing, personal controlling and internal control. The focus of her current research is the effectiveness of the internal audit in the light of human capital.

email address: lena.grzesiak@uni.lodz.pl 